\title{
Mathematical Evaluation Changes in Rheological and Mechanical Properties of Pears during Storage under Variable Conditions
}

\author{
Ayman H. Amer Eissa ${ }^{1,2}$, Abdul Rahman O. Alghannam ${ }^{1}$ and Mostafa M. Azam ${ }^{1,2}$ \\ 1. Department of Agriculture Systems Engineering, College of Agricultural and Food Sciences, King Faisal University, P.O. Box 420, \\ Al-Hassa 31982, Saudi Arabia \\ 2. Agriculture Engineering Department, Faculty of Agriculture, Minoufiya University, Shibin El-Kom, Egypt
}

Received: July 18, 2012 / Published: October 20, 2012.

\begin{abstract}
In order to better design, fabricate and control pear handling machine, we should take into account mechanical and rheological properties of pear fruits as related to handling process. The changes in rheological properties of pears stored at 5 , 15 , $25{ }^{\circ} \mathrm{C}$ and variable (fluctuating) temperature for 12 days were evaluated in terms of elasticity and viscosity parameters using creep tests. The elasticity and viscosity parameters in creep tests in general decreased with increase in storage time both under constant and variable storage conditions. For the variable storage condition, a bulk mean temperature calculated to account for a series combination of storage time and temperature to which the pears subjected. The changes in rheological properties due to variable storage temperature were described as a function of storage time. The result indicated that except the viscosity parameter of the Maxwell component of the four-element model, it was possible to describe the changes in rheological properties as a function of storage time, which are better physical parameters to estimate the quality of pears.
\end{abstract}

Key words: Modeling, rheological and mechanical properties, pears, storage, Burger's model, creep test.

\section{Introduction}

Storage of pears in bulk is essential to ensure continuous supply of raw material for household consumption as well as for the pear processing industry. However, fruits are living entities even after harvest, respire and transpire. These processes bring about physiological changes and water loss, which in turn affect the mechanical properties [1].

Firmness for many agricultural products is related to maturity of it. In general, firmness of fruits decreases gradually as they become more mature and decreases rapidly as they ripen. Overripe and damaged fruits become relatively soft; firmness can be used as a

Corsponding author: Ayman Hafiz Amer Eissa, Ph.D., professor, research fields: agricultural systems engineering, area of interest is process and food engineering. E-mail: aymanhafiz@kfu.edu.sa. criterion for sorting agricultural products into different maturity groups or for separating overripe and damaged fruits from good ones. Tao [2] mentioned that firmness is a physical property that is often used for evaluating the quality of fruits and vegetables. Bruise damage is a major cause of loss in many fruits. Bruising can result from post-harvest handling, packaging, and distribution. Fruit bruising is caused by compression, impact, and vibration forces during transportation and handling. It has been shown that these losses can be reduced by careful handling practices [3].

Pear is more sensitive to mechanical injury than other fruits such as apple and many stone cells distributed in flesh [4], it has been recognized that biomaterials exhibit visco-elastic behaviour when subjected to external loading. The visco-elasticity of 
fruits and vegetables has been investigated to improve textural quality [5-7]. However, in early studies reliable or accurate viscoelastic data were rarely available for pears because pear flesh tends to loss water and change physiologically over long experimental periods [8]. Fortunately, transient and dynamic measurements restricted to small deformations within the linear viscoelastic range of samples allow to characterize microstructure changes without disrupting the microstructure in the process $[6$, 9]. In particular, dynamic mechanical analysis using highly sensitive instruments is an effective method to monitor structural changes because it applies very small oscillatory shear strains (less than $0.1 \%$ ) on the samples over very short period, and thus the viscoelastic properties of fruits can be studied with minimal physical changes [10].

Rheology has been defined as "a science devoted to the study of deformation and flow". Therefore, when the action of force results in deformation and flow in the material, the mechanical properties will be referred to as rheological properties, moreover, rheology considers the time effect during the loading of a body [8].

The objectives of this study, therefore, were (1) to investigate and describe the changes in rheological properties of pears during storage under constant and variable storage conditions using quasi-static and visco-elastic tests; (2) investigate mechanical properties of pear related storage.

\section{Materials and Methods}

\subsection{Storage Condition}

Bartlett pears at commercial maturity, according to the skin color of the fruit, were harvested from a commercial orchard in Sadat, Minoufiya, Egypt. The pears were selected on the basis of absence of bruises and disease. Freshly harvested pears were purchased 2 days after harvest. Prior to storage, the pears were cleaned by washing to remove the adhering soil and other foreign materials and then dried to remove the moisture on the surface by spreading on cement floor for about 4-5 $\mathrm{h}$. The cleaned and surface-dried pears were put in plastic baskets and kept at room temperature $\left(24{ }^{\circ} \mathrm{C}\right)$ for a week [11]. Pears were withdrawn from their respective storage chambers and reconditioned at room temperature $\left(24^{\circ} \mathrm{C}\right)$ overnight before mechanical tests are conducted.

\subsection{Mechanical Properties}

\subsubsection{Coefficient of Static Friction}

The static coefficient of friction was measured under the condition of different surfaces [13], and it was used to measure the angle of friction for each of the studied samples on five different surfaces. The five surfaces are: a) Ply wood (c.s.f.w), b) Rubber (c.s.f.ru), c) Stainless steel (c.s.f.s), d) Iron (c.s.f.ir), e) Carton (c.s.f.car).

Samples were placed in the tray over the tested surface. The tray was tilted up around its pivoted side, and the angle of frication was displayed when the sample moved. The static coefficient of friction $(\mu)$ for the mentioned surfaces obtained uses the Eq. 1 [12].

$$
\mu=\tan \theta
$$

Where $\theta=$ the angle of tilt.

\subsubsection{Penetration Resistance and Firmness}

Digital instrument for measuring penetration resistance was used to measure firmness, or degree of softness or crispness, which is used worldwide as a test of ripeness and maturity for many vegetables and fruits (Effe-Gi, Ravenna, Italy). The maximum force (N) required to penetrate the sample was recorded and reported as the texture of the whole samples. At least three measurements were made on each fruit at different locations, and the results were averaged.

\subsubsection{Impact Test and Bruising Damage}

The impact test was conducted by falling of each pear from heights ranged from 0.10 to $0.40 \mathrm{~m}$ by using pendulum instrument as shown in Fig. 1 to apply the preselected amount of energy to the sample during impact within the portable folding pendulum. A dynamic sample tester was designed and built at the 


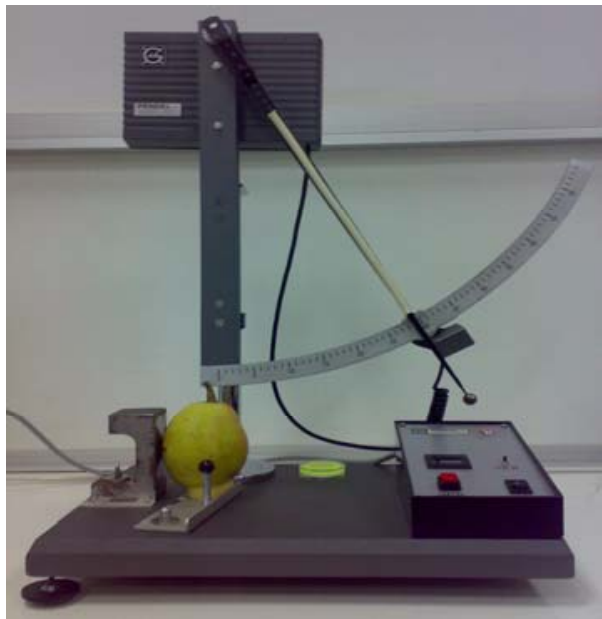

Fig. 1 The portable pendulum instrument. [13].

department of Agric. Eng Minufiya University and Gutsch Company, Nauendorf, Germany. Impact parameters such as impact velocity, rebound velocity, velocity ratio (coefficient of restitution), drop height, rebound height and rebound angle were monitored with damage volume and recorded in Figs. 4-6. [13]

After impact testing, pears were stored for three days at a temperature of $\left(20-22^{\circ} \mathrm{C}\right)$ for about $24-72 \mathrm{~h}$ to allow full development of the bruise. During this interval, the color of the bruised parts of the fruit flesh changed from the original to brown. The fruit was then cut in the middle of the two bruised spots perpendicularly to the fruit surface and the diameters (D) and depths (d) (in $\mathrm{cm}$ ) of the spots were measured as shown in Fig. 2. These were used to calculate the bruise volume of the individual spot based on the formula given by:

$$
\mathrm{V}\left(\mathrm{cm}^{3}\right)=\pi \mathrm{D}^{2} \frac{\mathrm{d}}{6}
$$

\subsection{Rheological Properties}

\subsubsection{Creep Test}

The procedure to conduct the creep test was run by using the creep test device. It was constructed specifically for the experiments according to the creep test device. The apparatus was calibrated to evaluate the relation between the nominal load and the effective load by the cross head on top of an electronic balance. The cross head was balanced by means of

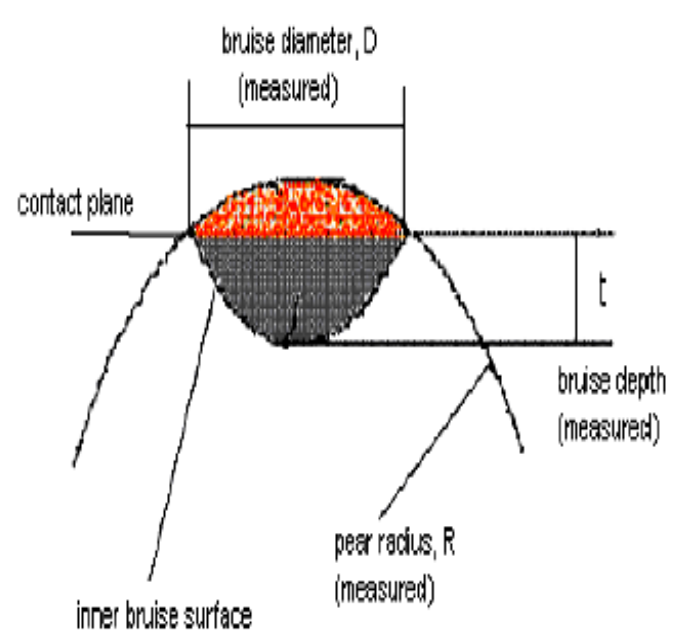

Fig. 2 Bruise volume calculation.

weights to touch the top of balance at zero load level. Then the cross head was loaded with different weights up to $3,000 \mathrm{~g}$, nominal load and the readings of balance were recorded (effective load).

The procedure to conduct the creep test was run by placing the pear fruit between two parallel plates. The fruit was placed on the base of the apparatus while the cross head was just touching the surface of it at zero loading condition. The fruit was loaded by a specific load, and the experiments were conducted at three levels of room temperature $\left(5,15,25{ }^{\circ} \mathrm{C}\right)$, the instantaneously deformation was indicated by dial micrometer and the reading of micrometer was continuously read as samples was deformed. The total test time was one-hour and distributed to two parts during the first half hour the fruit loaded and reading of micrometer was continuously read (creep period), while during the second half hour period the load lifted for fruit (retardation period), and then the test was finished.

Creep test experiments were conducted on pears as follows:

Three load levels $(10,14$, and $18 \mathrm{~N})$;

Three level of temperatures $\left(5,15\right.$ and $\left.25^{\circ} \mathrm{C}\right)$;

Two loading positions $(\mathrm{L}=$ Longitudinal; $\mathrm{D}=$ Radial).

2.3.2 Four-elements Model (Burgers' model)

The obtained data were used for plotting creep curves to calculate the various constants Burgers' 
modal $\left(E_{1}, E_{2}, \eta_{1}\right.$ and $\left.\eta_{2}\right)$ for pear under three loads during storage time. Under a constant load $\sigma$ we can distinguish between three types of deformation as shown in Fig. 3.

The spring: $\varepsilon_{1}=\sigma / E_{1}$

The Kelvin -Voigt element: $\varepsilon_{2}=\sigma / E_{2} \cdot\left[1-\exp \left(-E_{2}\right.\right.$. $\left.\left.t / \eta_{2}\right)\right]$

The dashpot: $\varepsilon_{3}=\sigma .\left(t / \eta_{1}\right)$

Constants Burgers' model was calculated by typical curve and using the following equation:

$$
\varepsilon=\sigma\left[\frac{1}{E_{1}}+\frac{1}{E_{2}}\left(1-\mathrm{e}^{-1 / \tau}\right)+\frac{t}{\eta_{1}}\right]
$$

Where:

$\varepsilon=$ The total deformation at any time $\mathrm{t} ; \mathrm{mm}$;

$\sigma=$ Constant load, $\mathrm{N}$;

$\mathrm{E}_{1}=$ Instantaneous elasticity, $\mathrm{N} / \mathrm{mm}$;

$\mathrm{E}_{2}=$ Retarded elasticity, $\mathrm{N} / \mathrm{mm}$;

$\eta_{1}=$ Free viscous element, N. min/mm;

$\eta_{2}=$ Retarded viscous element, N. min/mm; and

$\tau=\eta_{2} / E_{2}$ it is retardation time of the Kelvin portion of the model, sec.

\section{Results and Discussion}

\subsection{Mechanical Properties}

\subsubsection{Coefficient of Friction}

The coefficient of static friction variation with storage time was displayed in Fig. 4 for different materials. The coefficient of static friction, at all different storage time is considered highest on pear surface followed by iron, wood, rubber, stainless-steel then carton, because the adhesion forces between the samples and surface materials increase when using rough materials such as wood and rubber. Similar results were found by Kabas et al. [14] for cactus pears.

Coefficient of static friction increased with the increasing in pear storage time. The largest coefficient of static friction was the coefficient iron surface. The relationship between coefficient of static friction for wood, stainless steel, rubber, iron, and carton surfaces with pears storage time can be represented by following equations:

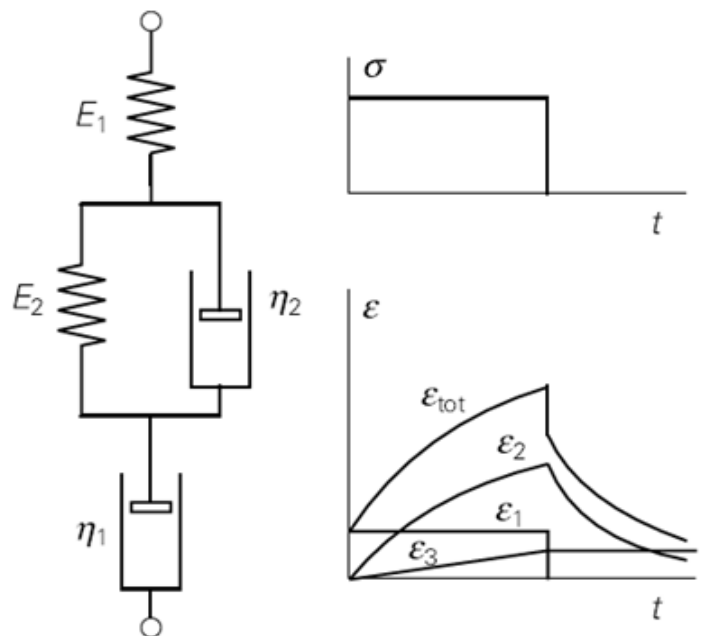

Fig. 3 Creep of the four-element model (Burgers' model).

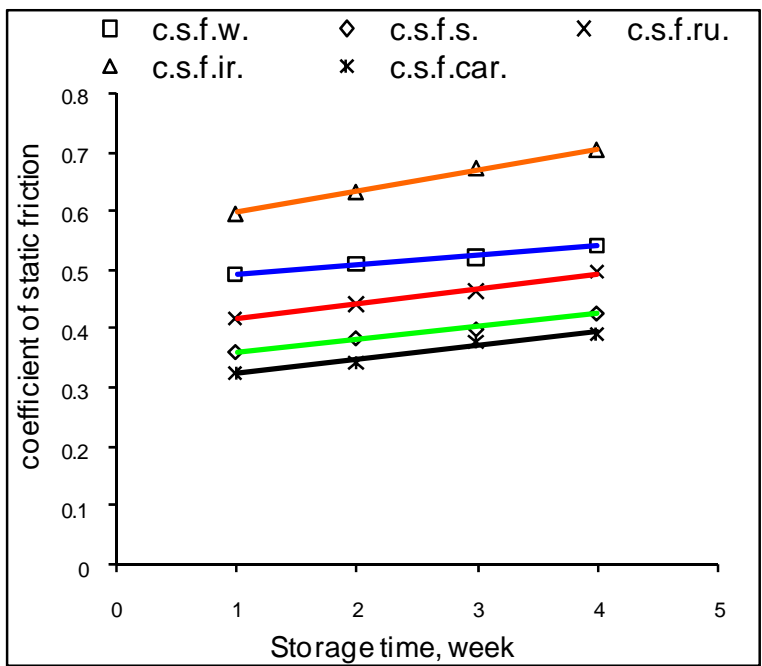

Fig. 4 Effect of storage time on coefficient of static friction of pear.

$$
\begin{aligned}
& \mu_{\mathrm{W}}=0.4761+0.016 \text { S.T }\left(\mathrm{R}^{2}=0.99\right) \\
& \mu_{\mathrm{S}}=0.3392+0.0217 \text { S.T }\left(\mathrm{R}^{2}=0.99\right) \\
& \mu_{\mathrm{ru}}=0.3938+0.025 \text { S.T }\left(\mathrm{R}^{2}=0.99\right) \\
& \mu_{\mathrm{Ir}}=0.5617+0.0361 \text { S.T }\left(\mathrm{R}^{2}=0.99\right) \\
& \mu_{\mathrm{car}}=0.3021+0.0236 \text { S.T }\left(\mathrm{R}^{2}=0.97\right)
\end{aligned}
$$

\subsubsection{Firmness $\left(\mathrm{N} / \mathrm{mm}^{2}\right)$}

The results of the firmness $(F)$ tests during storage period are presented in Fig. 5. The results show that the firmness increased by increasing storage time then decreased.

For all pear samples, greater forces were recorded at second week period previously. The minimum firmness was recorded at the end of storage period. This variation in values of firmness may be due to a 


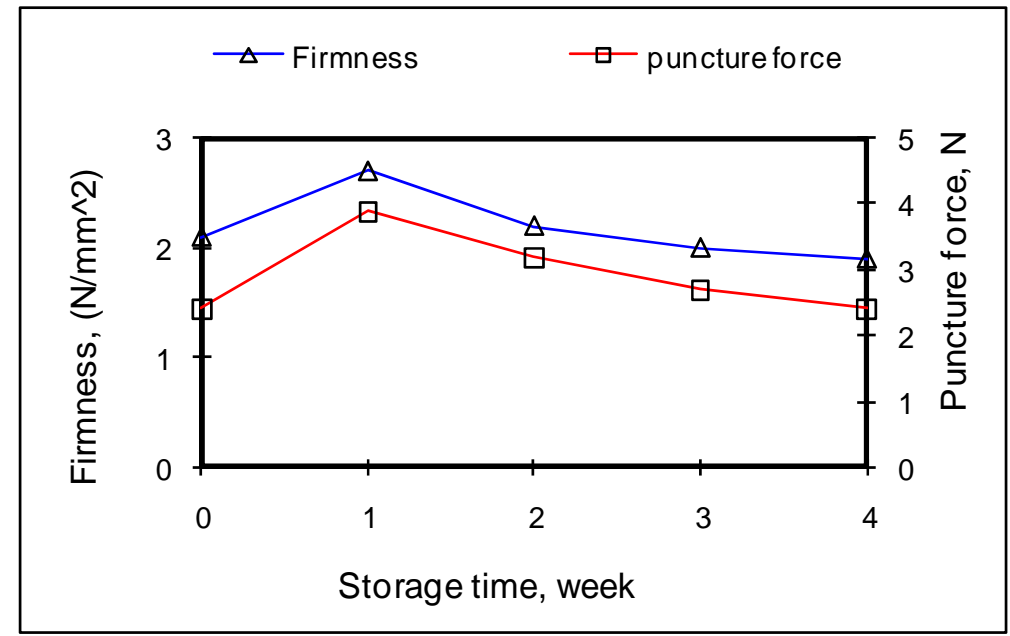

Fig. 5 Firmness and puncture force vs storage time for pear.

number of physical and chemical factors contributing to sample resistance to breakdown as pectin materials in cell wall, size of cells, dry matter content and specific gravity.

The values of firmness of pear tissue increased during the first week due to the high percentage of water loss while it decreased during the second week up to the third week from the havest-day. This may be due to some physical and chemical factors occurred in the pear samples as changing some carbohydrate material into sugar material and pear shrinkage due to the high water loss percentage particularly during the period of first week from harvest-day, due to increasing in the biological operations as the high breathing rate and the high of water loss percentage through the opening cellular. These results lead to determinate the best period for handling operation of pear, which was found the second week from harvest-day where the least rate of mechanical damage was obtained.

$$
\mathrm{F}_{\text {Pear }}=1.96+0.3614 \mathrm{ST}-0.0786 \mathrm{ST}^{2} ; \mathrm{R}^{2}=0.53
$$

\subsubsection{Puncture Force (N)}

The results of the puncture force tests were presented in Fig. 5. The results showed that the puncture force was grading increased by increasing storage time then decreased. For pear samples, greater forces were necessary to penetrate pears at storage period. The minimum puncture forces of pears up to the end of storage period observed.

Regression analysis was applied to the data of pear puncture force and storage time. The equation was as follows:

$$
P_{f \text { Pear }}=1.58+1.3371 S T-0.2429 S T^{2} \mathrm{R}^{2}=0.59
$$

During storage pears lose dry matter, mainly carbohydrates, which are converted into carbon dioxide and water [15]. At the same time, transpiration of pears causes loss of water which is often the most serious cause of weight loss during storage [2]. Therefore, changes in mechanical properties of pears over time must be related to both transpiration and respiration. During storage, the cellular membranes of pear cells are likely to have undergone structural disruptions so that turgor pressure decreases, and the stresses imposed on the cellular assembly are lessened [16].

\subsubsection{Pendulum Impact}

The use of pendulum to estimate the susceptibility of pear damage is important to limit the impact velocity, energy absorbed, change of momentum absorbed and coefficient of restitution. It can be seen as shown in Fig. 6 the energy absorbed with pear is increased by increasing impact velocity. The energy absorbed was also increased by increasing drop height. The data also indicated that the energy absorbed at cylindrical impactor for pear was increased from 0.50 to $1.00 \mathrm{~J}$ by increasing impact velocity from 1.40 to 

of Pears during Storage under Variable Conditions

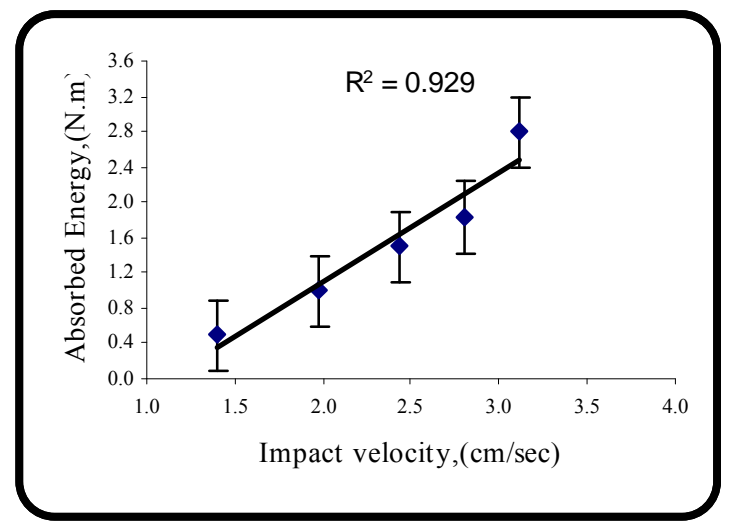

Fig. 6 Impact velocity vs absorbed energy for pears.

$1.98 \mathrm{~cm} / \mathrm{sec}$, the energy absorbed was also increased from 0.50 to $1.50 \mathrm{~J}$ by increasing impact velocity from 1.40 to $2.43 \mathrm{~cm} / \mathrm{sec}$, these results mean that the energy absorbed by pear at highest velocity was $2.80 \mathrm{~J}$ and the lowest velocity $0.50 \mathrm{~J}$.

$$
E_{\text {Absorbed }}=1.24 \mathrm{Imp} \text { Vel }-1.38 R^{2}=0.93
$$

The coefficient of restitution (e) was 0.34, 0.24, 0.21 and 0.18 for impact velocity of $1.40,1.98,2.43$ and $2.80 \mathrm{~cm} / \mathrm{sec}$ respectively as shown in Fig. 7. This result indicated that when impact velocity increased, there will be coefficient of restitution decreased. As the impact velocity increases, the amount of plastic deformation increases, there will be a decrease in coefficient of restitution. This dynamic behavior was illustrated in Fig. 8.

$$
e=0.4708-0.1051 \text { Imp Vel } R^{2}=0.96
$$

Concerning change of momentum absorbed of pears relationship with impact velocity as shown in Fig. 8 also showed that the change of momentum absorbed was increasing by increasing the impact velocity.

$$
M_{\text {Abs }}=0.527 \text { Imp Vel }-0.2554 R^{2}=0.998
$$

Concerning coefficient of restitution of pears relationship with impact energy as shown in Fig. 9 also showed that the coefficient of restitution was decreasing by increasing the impact energy.

$$
e=0.3576-0.0872 \text { IE } R^{2}=0.981
$$

Concerning bruise volume of pears relationship with impact energy as shown in Fig. 10 also showed that the bruise volume was increasing by increasing the impact energy and severe external damage occurred at the higher impact energies which would

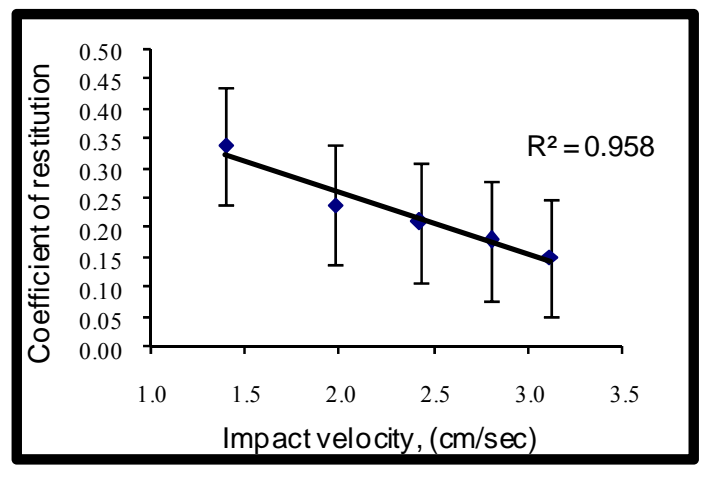

Fig. 7 Impact velocity vs coefficient of restitution for pears.

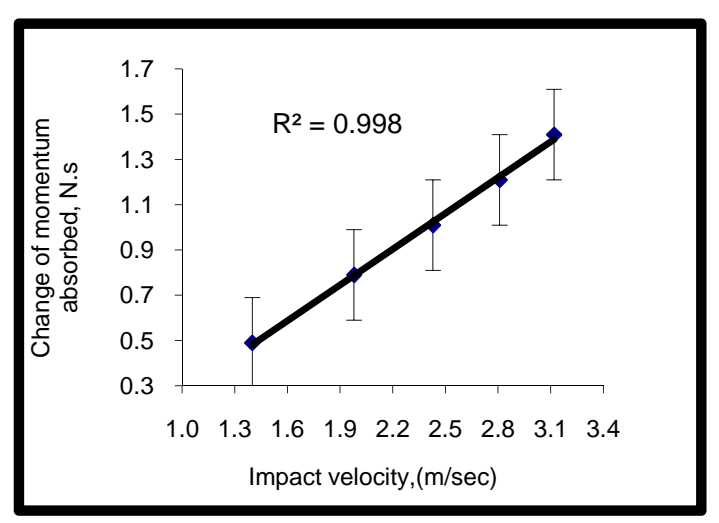

Fig. 8 Impact velocity vs momentum absorbed for pears.

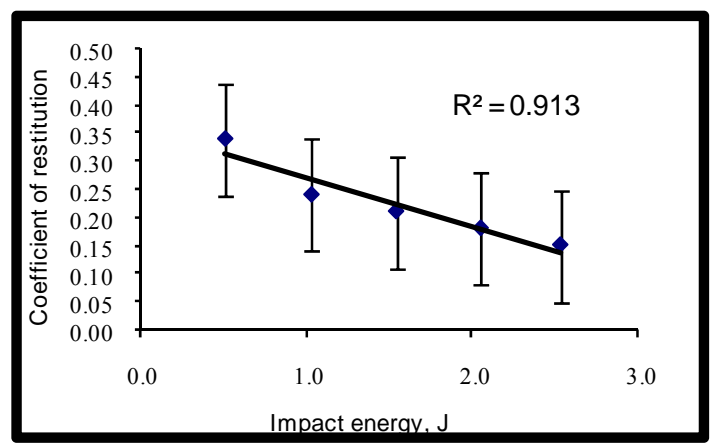

Fig. 9 Impact energy vs coefficient of restitution for pears.

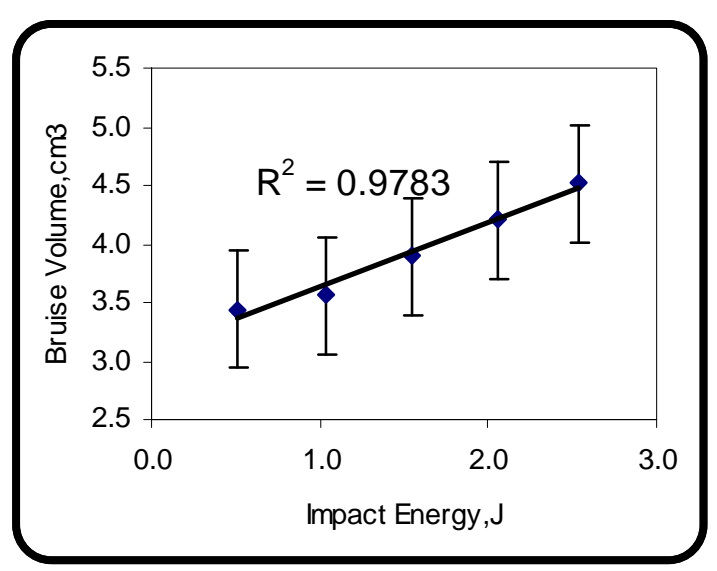

Fig. 10 Impact energy vs Bruise volume for pears. 


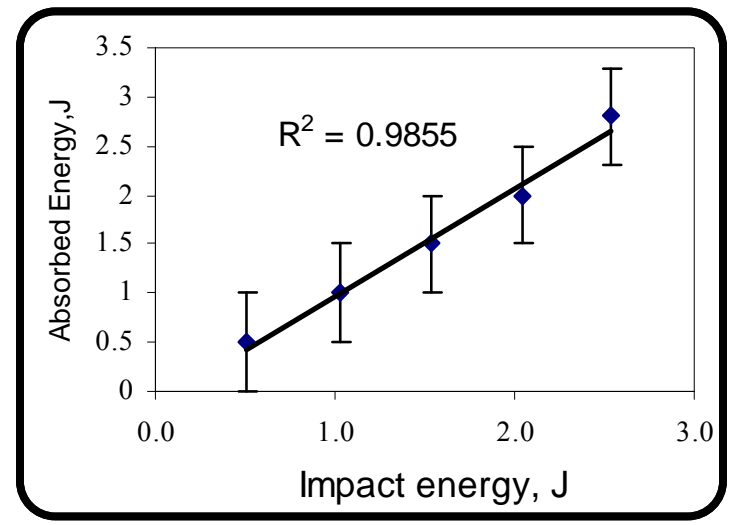

Fig. 11 Impact energy vs absorbed energy for pears.

result in a proportionately higher energy absorption and decrease in coefficient of restitution [17].

$$
B_{v o l}=0.5545 I E+3.0745 R^{2}=0.98
$$

This result matched that of [7] who reported that the energy absorbed and the change of momentum absorbed provide better expression of load than total energy and total momentum.

Concerning absorbed energy of pears relationship with impact energy as shown in Fig. 11 also showed that the absorbed energy was increasing by increasing the impact energy.

$$
E_{\text {Abs }}=1.1049 \mathrm{IE}-0.1326 R^{2}=0.99
$$

The results show that bruise which results from the disruption of the cell contents was closely related to the deformation of the pear. Pear tissue is a viscoelastic material and its strain is therefore time dependent and explains why apples deformed more for a given energy absorption when the energy was applied over a relatively long duration [17].

\subsection{Rheological Properties}

\subsubsection{Changes Rheological Parameters during Storage}

Fig. 12 shows typical creep test curves and the rheological constants of Burgers model for pear using $10 \mathrm{~N}$ static loads at the pear harvesting day. Considerable variations were obtained throughout the results of the creep tests on individual pear. Two reasons for this are the non-homogenous nature of pear sample and the stress concentration set up by its irregular shape or surface. The latter is considered to be an important factor which is apparent through comparing the results of pears tested at longitudinal and radial axis position. The mean creep data which were obtained from tests were analyzed by Four-element model (Burgers model) to determine the model constants $\left(\mathrm{E}_{1}=\right.$ Instantaneous elasticity, $\mathrm{N} / \mathrm{mm}$; $\mathrm{E}_{2}=$ Retarded elasticity, $\mathrm{N} / \mathrm{mm} ; \eta_{1}=$ Free viscous element, $\mathrm{N} \mathrm{min} / \mathrm{mm}$; and $\eta_{2}=$ Retarded viscous element, $\mathrm{N} \mathrm{min} / \mathrm{mm}$ ) as the following:

Typical creep responses of cylindrical test specimens of fresh pears and pears stored at $15{ }^{\circ} \mathrm{C}$ under a step load of $10 \mathrm{~N}$ was presented in Fig. 13. The creep curves were best characterized by a four element Burger model $\left(\mathrm{R}^{2}=0.95-0.99\right)$ consisting of an instantaneous elasticity $\left(E_{1}\right)$, free viscous element $\left(\eta_{1}\right)$, retarded elasticity $\left(E_{2}\right)$, and retarded viscosity $\left(\eta_{2}\right)$ parameters represented by Equation for the series combination of a Maxwell and Kelvin models in Fig. 3. For fresh pear tissue the value of $E_{2}$ was found to be more than 1 time that of $E_{1}$ indicating greater elasticity associated with this component of the four-element model, whereas $\eta_{1}$ was about 3 times the value of $\eta_{2}$ reflecting less fluidity of the structural component associated with this unit. The magnitude of the elasticity parameters $E_{1}$ and $E_{2}$ for fresh pear samples were determined to be 62.50 and $71.43 \mathrm{~N} / \mathrm{mm}$, whereas the viscosity parameters $\eta_{1}$ and $\eta_{2}$ were 2,500 and $779.56 \mathrm{~N} \mathrm{~min} / \mathrm{mm}$ in longitudinal position, respectively.

The instantaneous deformation of test specimens when subjected to the constant step load increased with increase in storage time under all storage conditions.

3.2.2 Modeling Changes in the Rheological Parameters under Constant Storage Condition.

\subsubsection{Instantaneous Elasticity $\left(\mathrm{E}_{1}\right)$}

Figs. 13 and 14 show the instantaneous elasticity $\left(E_{1}\right)$ decreased during storage time for pear at three levels of room temperature $\left(5,15\right.$ and $\left.25{ }^{\circ} \mathrm{C}\right)$. The instantaneous elasticity $\left(E_{1}\right)$ values increased as the room temperature increased, its values increased as the static load increased from $10 \mathrm{~N}$ to $18 \mathrm{~N}$. Significant 

of Pears during Storage under Variable Conditions

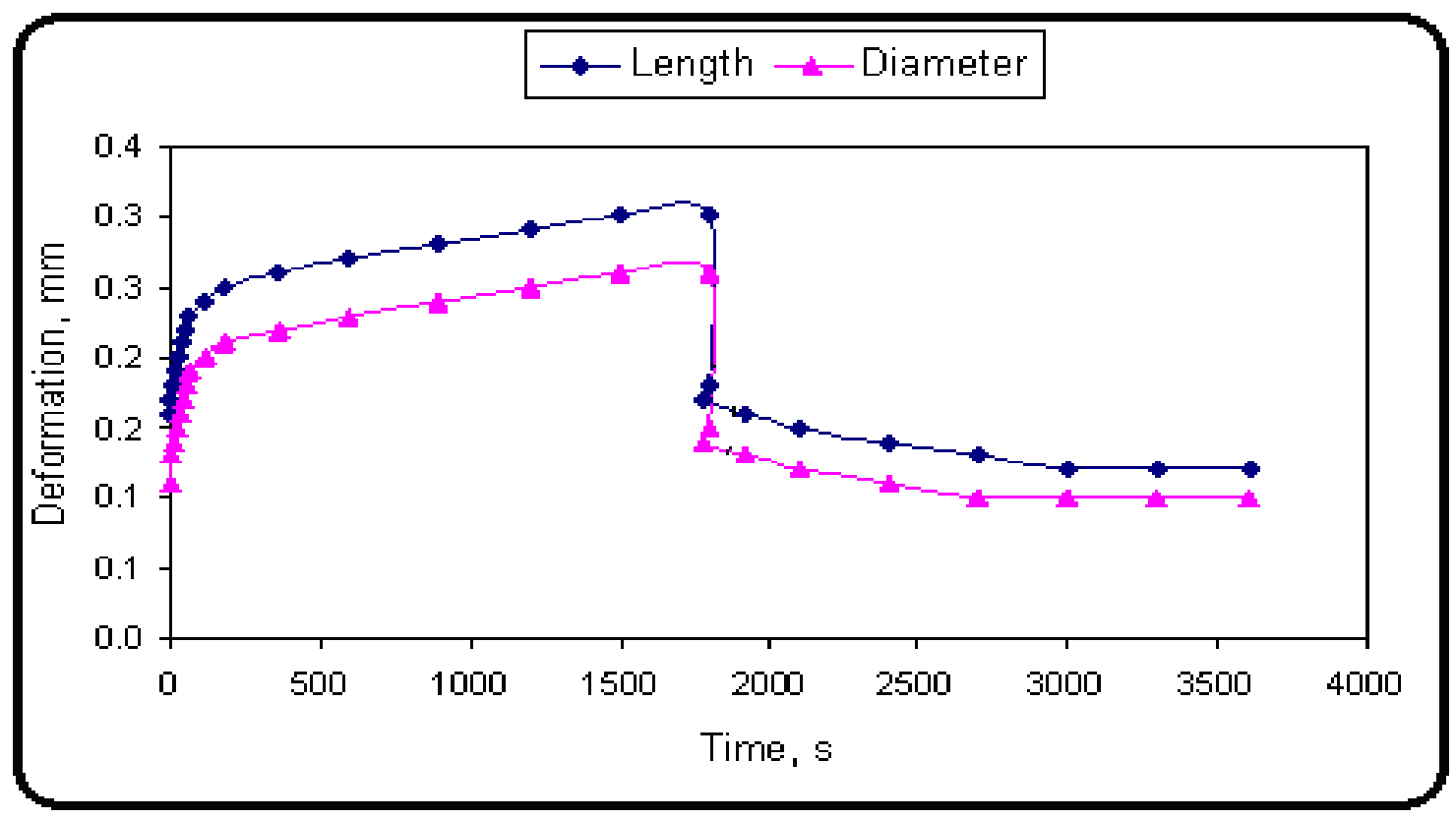

Fig. 12 Typical curve of creep retardation test for pear at load $10 \mathrm{~N}$ at room temperature.

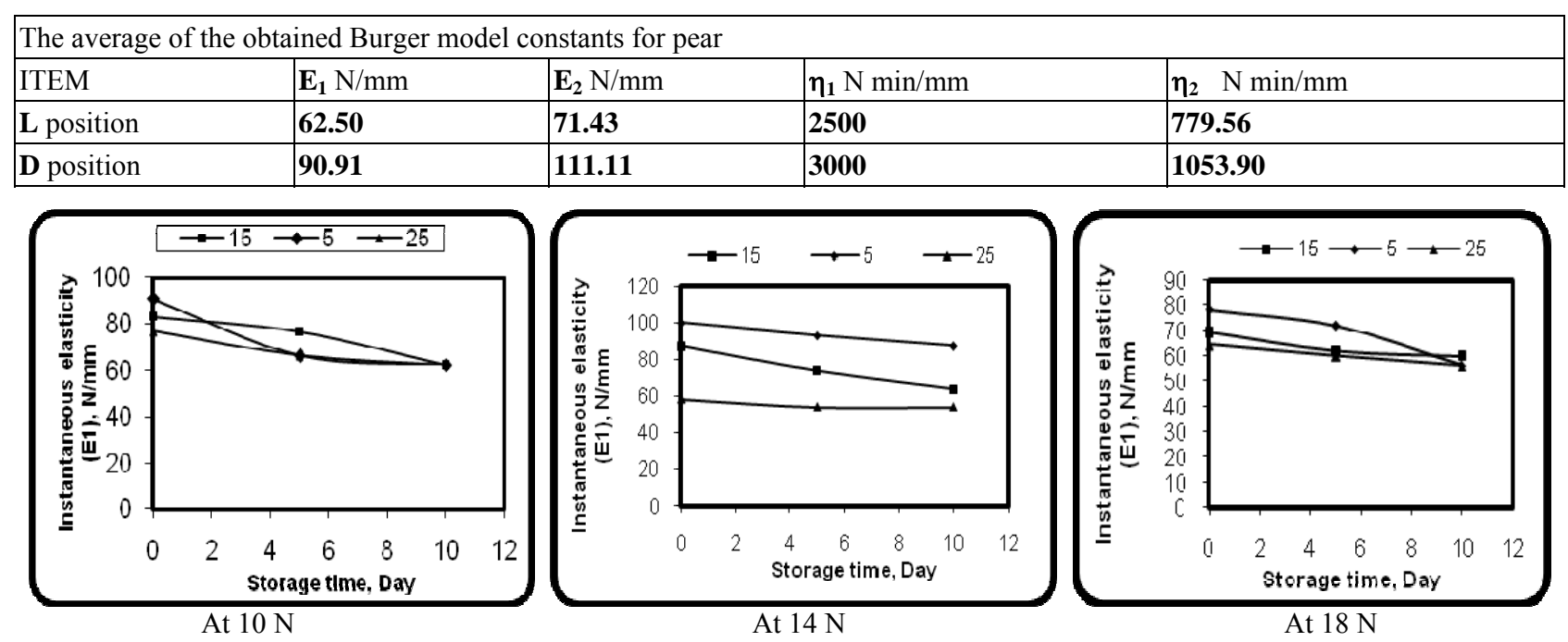

Fig. 13 Relationship between instantaneous elasticity $\left(E_{1}\right), \mathrm{N} / \mathrm{mm}$, for pears at loading position (Longitudinal $\left.(L)\right)$ for 10, 14 and $18 \mathrm{~N}$ of static load and three levels of room temperature $\left(5,15,25{ }^{\circ} \mathrm{C}\right)$.

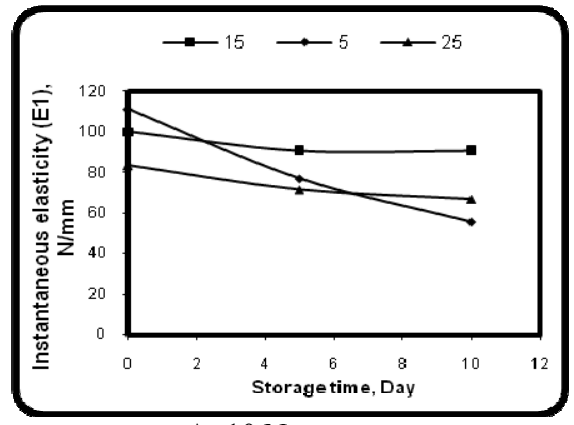

At $10 \mathrm{~N}$

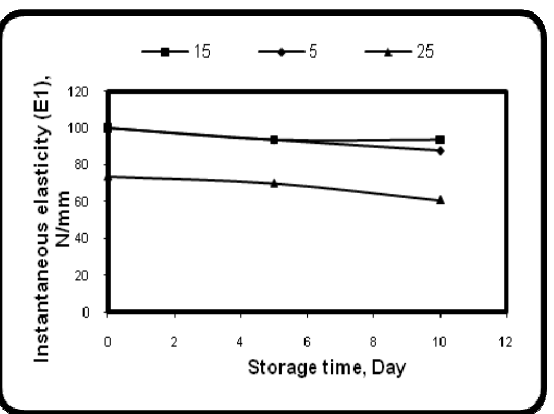

At $14 \mathrm{~N}$

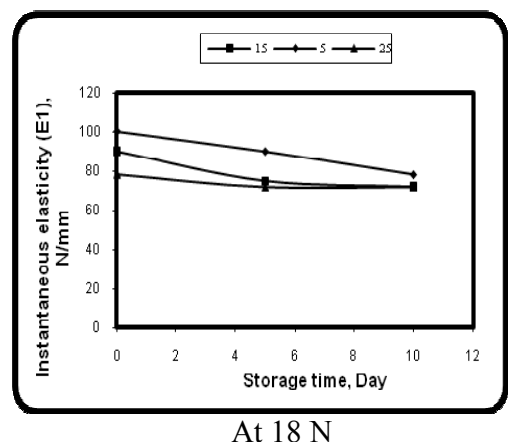

At $18 \mathrm{~N}$

Fig. 14 Relationship between instantaneous elasticity $\left(E_{1}\right), \mathrm{N} / \mathrm{mm}$, for pears at loading position (Radial axis (D)) for 10, 14 and $18 \mathrm{~N}$ of static load and three levels of room temperature $\left(5,15,25{ }^{\circ} \mathrm{C}\right)$. 
differences between the retarded elasticity $\left(\mathrm{E}_{1}\right)$ values for all three levels room temperature observed for all samples. The instantaneous deformation of tested samples specimens when subjected to the constant step load increased with increasing the storage time under all levels of room temperature. This increase in deformation led to a significant reduction in the values of $E_{1}$. The fresh pear exhibited a straight-line relationship, which is typical of elastic materials, whereas the stored pear showed a curve linear relationship below that of fresh pear indicating the loss of firmness. It has been reported that these changes in the mechanical properties of pears during storage are due to loss of turgor pressure and other biochemical reactions and returned to change in room temperature which affect the cell wall and middle lamella of the tissue $[18,19]$. And it has been found that the values of $\mathrm{E}_{1}$ determined at different storage systems decreased with increase in compression levels. From these data, in general, the instantaneous elasticity $\left(E_{1}\right)$ is inversely proportional with storage time.

\subsubsection{Retarded Elasticity $\left(\mathrm{E}_{2}\right)$}

The results of the retarded elasticity $\left(\mathrm{E}_{2}\right)$ were presented in Figs. 15 and 16. The results showed that retarded elasticity $\left(\mathrm{E}_{2}\right)$ decreased by increasing storage time at room temperature levels. Its values increased as the room temperature increased, and its values increased as the static load increased from $10 \mathrm{~N}$ to $18 \mathrm{~N}$.

Significant differences between the retarded elasticity $\left(E_{2}\right)$ values for all three levels of room temperature were observed for all samples, and differences retarded elasticity as well as their interaction was significant in three loaded positions of fruit. In the same time, there were significant differences when using the three levels of load as affected by storage time. From these data, in general, the retarded elasticity $\left(E_{2}\right)$ is inversely proportional with storage time.

\subsubsection{Free Viscous Element $\left(\eta_{1}\right)$}

The results of free viscous element $\left(\eta_{1}\right)$ were presented in Figs. 17 and 18. The results show that free viscous element $\left(\eta_{1}\right)$ decreased by increasing storage

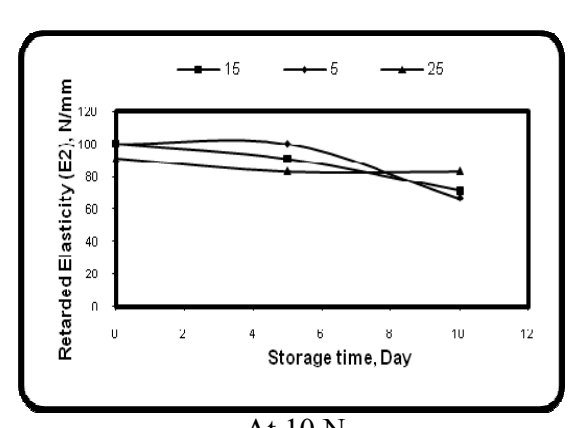

At $10 \mathrm{~N}$

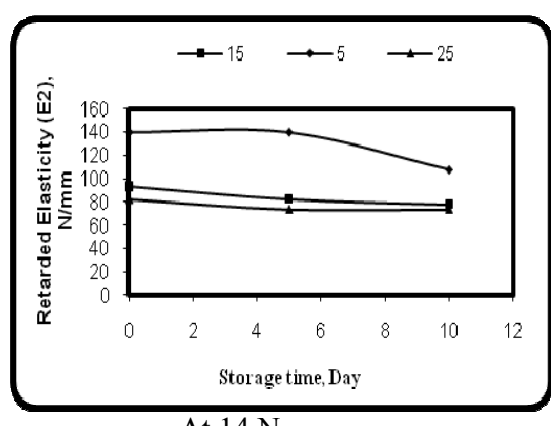

At $14 \mathrm{~N}$

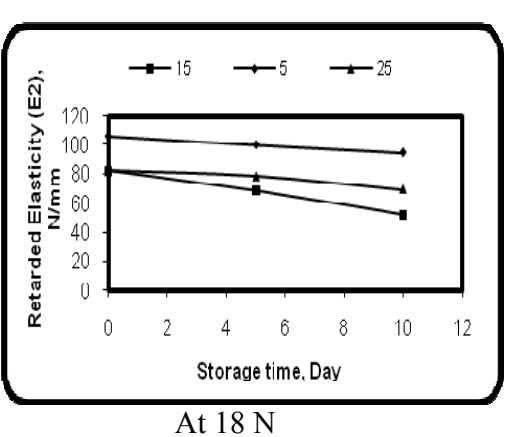

Fig. 15 Relationship between retarded elasticity $\left(E_{2}\right), \mathrm{N} / \mathrm{mm}$, for pears at loading position (Longitudinal (L)) for 10, 14 and $18 \mathrm{~N}$ of static load and three levels of room temperature $\left(5,15,25^{\circ} \mathrm{C}\right)$.

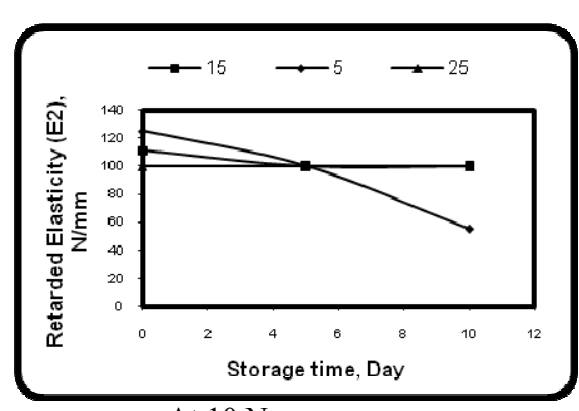

At $10 \mathrm{~N}$

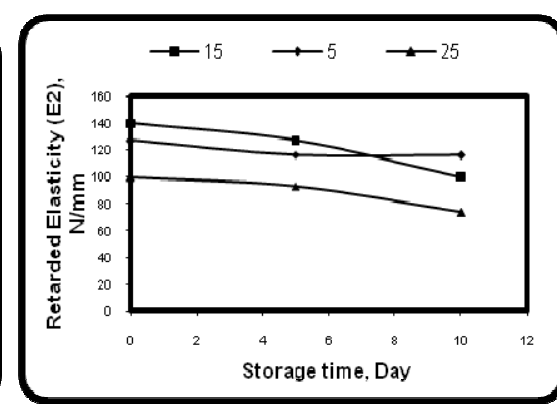

Storage time, Day

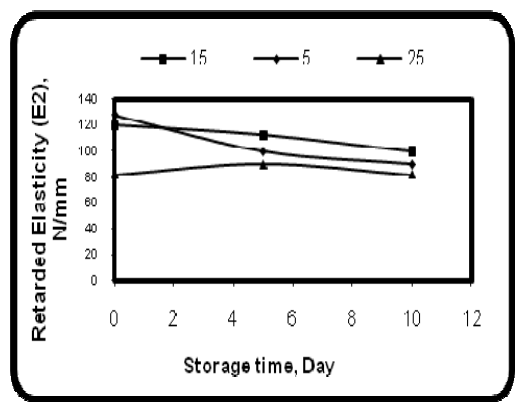

At $14 \mathrm{~N}$ At $18 \mathrm{~N}$

Fig. 16 Relationship between retarded elasticity $\left(E_{2}\right), N / m m$, for pears at loading position (Radial axis (D)) for 10, 14 and 18 $\mathrm{N}$ of static load and three levels of room temperature $\left(5,15,25^{\circ} \mathrm{C}\right)$. 


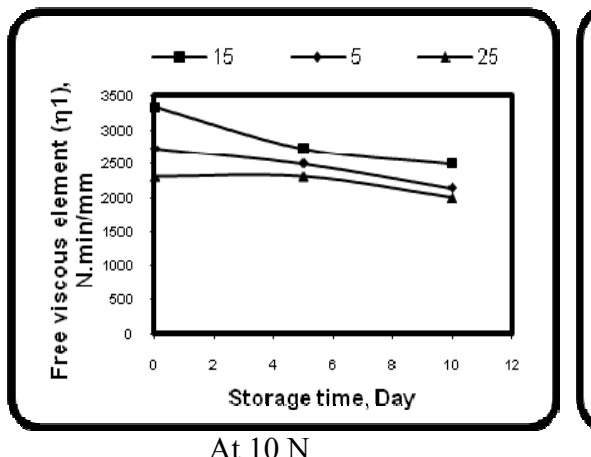

At $10 \mathrm{~N}$

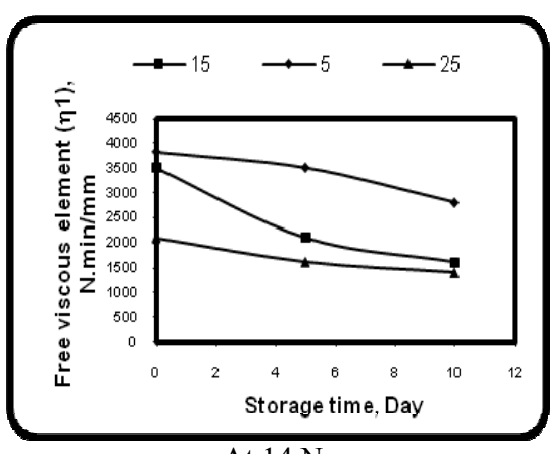

At $14 \mathrm{~N}$

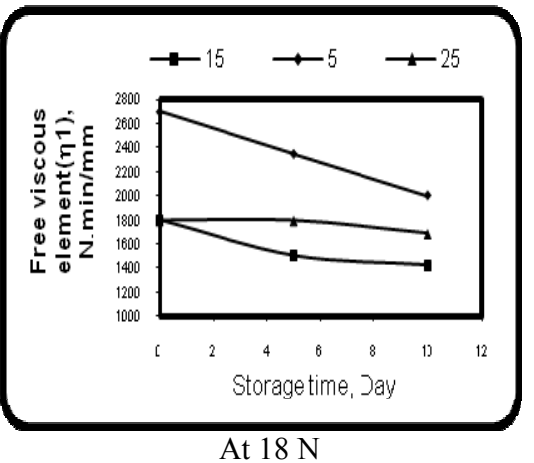

At $18 \mathrm{~N}$

Fig. 17 Relationship between free viscous element $\left(\eta_{1}\right)$, N.min/mm, for pears at loading position (Longitudinal (L)) for 10, 14 and $18 \mathrm{~N}$ of static load and three levels of room temperature $\left(5,15,25{ }^{\circ} \mathrm{C}\right)$.

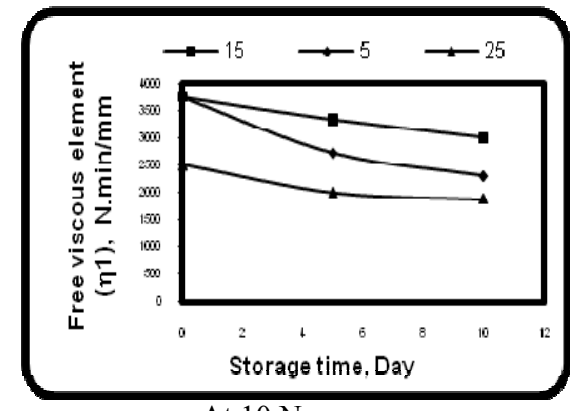

At $10 \mathrm{~N}$

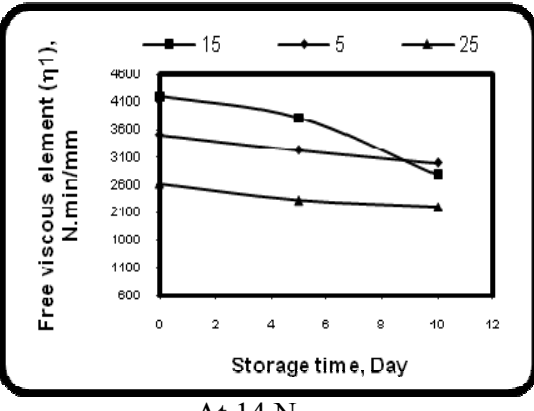

At $14 \mathrm{~N}$

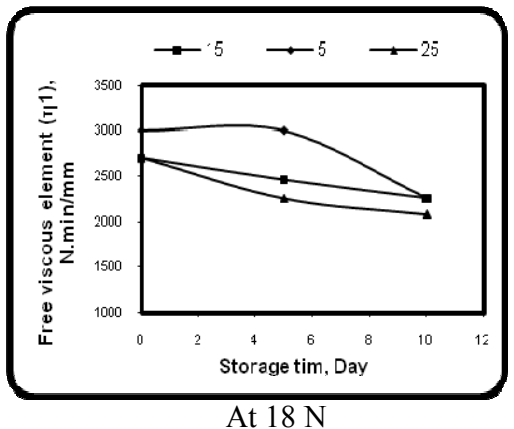

Fig. 18 Relationship between free viscous element $\left(\eta_{1}\right)$, N.min/mm, for pears at loading position (Radial axis (D)) for 10, 14 and $18 \mathrm{~N}$ of static load and three levels of room temperature $\left(5,15,25{ }^{\circ} \mathrm{C}\right)$.

time for pear tested at three levels of room temperature $\left(5,15\right.$ and $\left.25^{\circ} \mathrm{C}\right)$. The free viscous element $\left(\eta_{1}\right)$ values increased as the room temperature increased, its values increased as the static load increased from $10 \mathrm{~N}$ to $18 \mathrm{~N}$.

Significant differences between free viscous element $\left(\eta_{1}\right)$ values for all different room temperature levels were shown for all fruits. There were significant differences between free viscous element and the three positions of sample load. From these data, in general, the free viscous element $\left(\eta_{1}\right)$ is inversely proportional with storage time.

\subsubsection{Retarded Viscous Element $\left(\eta_{2}\right), \mathrm{N}$ min/mm}

The results of the retarded viscous element $\left(\eta_{2}\right)$ were presented in Figs. 19 and 20. It is clear that retarded viscous element $\left(\eta_{2}\right)$ decreased by increasing storage time at room temperature levels. This reduction in the values of $E_{2}$ and $\eta_{2}$ was most probably due to the degradation of pectin substances, which make up $45 \%$ of pear cell wall and are responsible for the binding of the cells together [18, 20].
The retarded viscous element at room temperature is higher than low room temperature. The retarded viscous element magnitudes increased by increasing the static load from $10 \mathrm{~N}$ to $18 \mathrm{~N}$. Significant differences were shown among different room temperature levels for all fruits. And differences in retarded viscous element as well as their interaction were significant in three loaded positions of fruit. From these data, in general, the retarded viscous element $\left(\eta_{2}\right)$ is inversely proportional with storage time.

The mechanical parameters defined creep behavior. According to interpretation [7], 1/ $\mathrm{E}_{1}$ should be related to those bonds of structural units that are stretched elastically when the stress is applied; and show instantaneous and complete recovery when the stress is removed. $1 / \mathrm{E}_{2}$ parameters would be related to bonds that break and reform at different rates, the weaker bonds breaking at smaller values of time than the stronger ones. They show retarded elastic recovery. The linear region of Newtonian compliance $t / \eta_{1}$ should be related to those bonds that are ruptured 

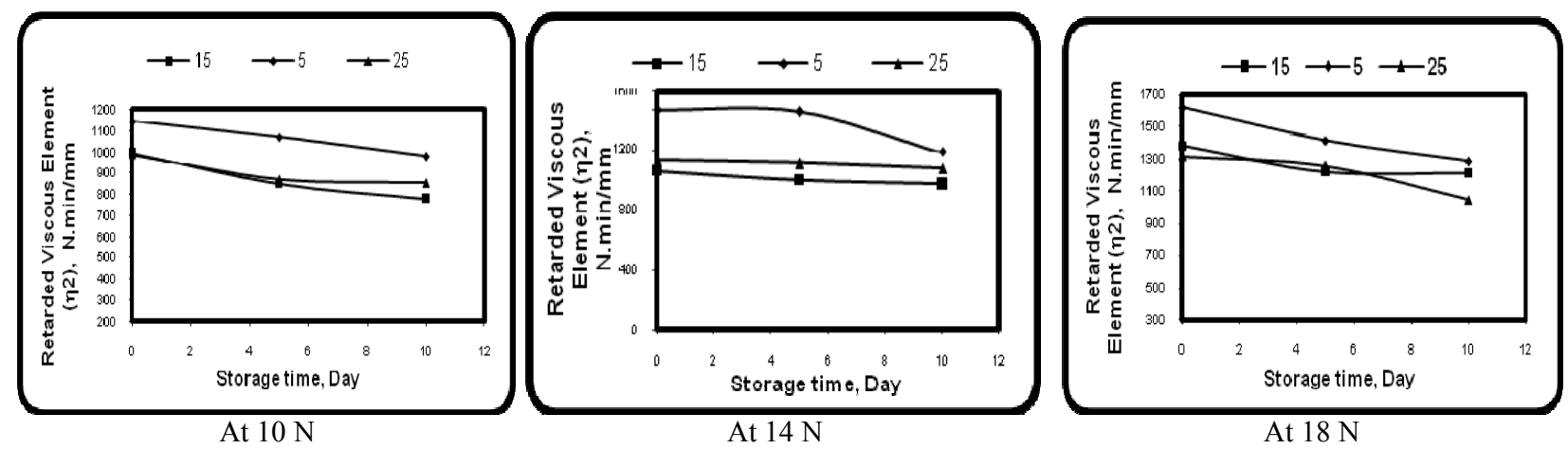

Fig. 19 Relationship between retarded viscous element $\left(\eta_{2}\right), \mathrm{N}$ min/mm, for pears at loading position (Longitudinal (L)) for 10,14 and $18 \mathrm{~N}$ of static load and three levels of room temperature $\left(5,15,25^{\circ} \mathrm{C}\right)$.

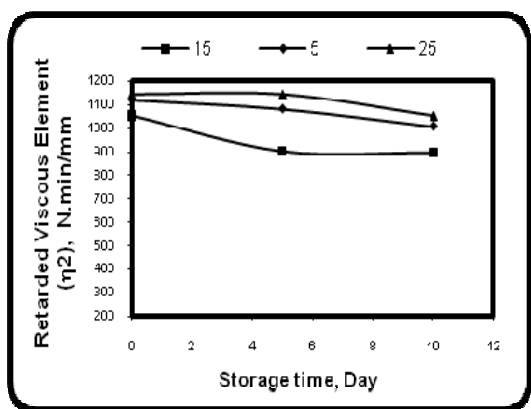

At $10 \mathrm{~N}$

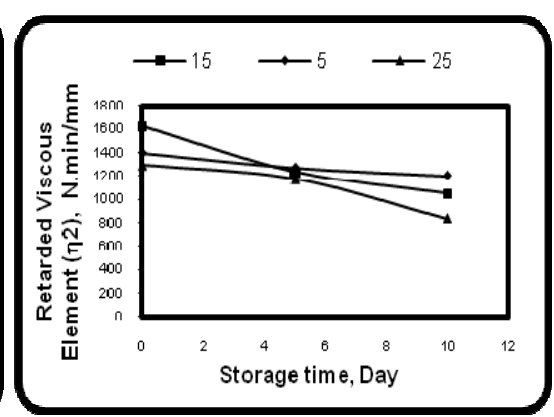

At $14 \mathrm{~N}$

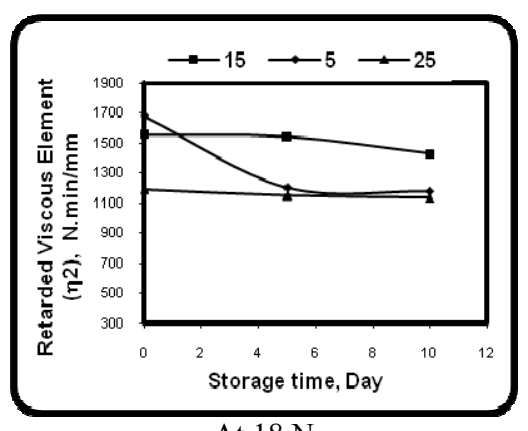

At $18 \mathrm{~N}$

Fig. 20 Relationship between retarded viscous element $\left(\eta_{2}\right)$, N.min/mm, for pears at loading position (Radial axis (D)) for 10, 14 and $18 \mathrm{~N}$ of static load and three levels of room temperature $\left(5,15,25^{\circ} \mathrm{C}\right)$.

during the shear creep step and the time required for them to reform is longer than the creep-recovery period. The released units will flow and part of the structure is not recovered. The pronounced effects of pear on transient mechanical properties of pear tissue can be found in Fig. 12, suggesting that all pear samples retained considerable plastic (i.e., unrecovered) strain in the creep-recovery test. As the turgor reduced, the overall compliance at the end of the creep phase showed a significant increase. The instantaneous elastic compliance $\left(1 / \mathrm{E}_{1}\right)$ and steady-state viscous compliance $\left(1 / \eta_{1}\right)$ showed falling trends with the turgor increasing. The overall reduction in $\left(1 / \mathrm{E}_{1}\right)$ and $\left(1 / \eta_{1}\right)$ indicated that the high-turgor tissue was more brittle while the low-turgor tissue was more ductile. Consequently, flaccid pear tissue (i.e. tissue that has low turgor) had a greater apparent fluidity of tissue than turgid tissue, associated with a greater permanent deformation during the shear creep step. This makes us believe that turgor adjustment can influence the susceptibility to mechanical damage and these findings are in agreement with the research [21].

\section{Conclusions}

A modified exponential model successfully represented the changes in the rheological properties of pears due to storage under constant condition using creep tests.

The changes in the rheological properties of pears under fluctuating storage condition could be adequately described as a storage time.

The best period for pears handling is the second week after harvesting period to minimize the mechanical damage.

Increasing drop heights leads not only to a higher percentage of bruises, but to a shift in type of bruise.

It is recommended to put the pears in the packages on minimum axis position (D) so that it leads to less deformation under loads. 


\section{References}

[1] W.G. Burton, The Potato, UK: Longman Scientific and Technical, 1989.

[2] S.R. Tao, Studies on the relationship among the structure store resistance and quality of fruit of pear, Acta Botanica Boreali-occidentalia Sinica 20 (4) (2000) 544-548.

[3] P. Chen, Z. Sun, A review of non-destructive methods for quality evaluation and sorting of agricultural products, J. agric. Engng. Res. 49 (1991) 85-98.

[4] V. Chonhenchob, S.P. Singh, Testing and comparison of various packages for mango distribution, Journal of Testing and Evaluation 32 (2004) 4.

[5] J.D. Baerdemaeker, L.J. Segerlind, Determination of the viscoelastic properties of apple flesh, ASAE Paper No. 74-3512, 1976,

[6] R.E. Pitt, H.L. Chen, Time-dependent aspects of the strength and rheology of vegetative tissue, Transactions of the ASAE 26 (4) (1983) 1275-1280.

[7] I. Sadato, K. Takayuki, Studies on mechanical properties of agricultural products (Part 2), Journal of the Japanese Society of Agricultural Machinery 32 (1) (1970) 59-64.

[8] N.N. Mohsenin, Physical properties of plant and animal materials 2nd ed., New York: Gordon \& Breach Science, 1986.

[9] J. Wang, Q.J. Lu, The steady-state sinusoidal dynamic behaviour of peach and pear, Biosystems Engineering 87 (4) (2004) 463-469.

[10] R.S. Lakes, Viscoelastic measurement techniques, Review of Scientific Instruments 75 (4) (2004) 797-810.

[11] C.P. Meijers, Wound healing, in: A. Rastovsky (Ed.), Storage of Potato: Postharvest Behavior, Storage Design, Storage Practice, Handling, Wageningen: Pudoc. pp.
328-341.

[12] K.K. Singh, T.K. Gowswami,. Physical properties of cumin seeds, J. Agric. Eng. Rec. 64 (1996) 93-98.

[13] A.H. Amer Eissa, A portable pendulum for impact characterization of whole eggshell, Misr J. Ag. Eng. 21 (2004) 1-13.

[14] O. Kabas, A. Ozmerzi, I. Akinci, Physical properties of cactus pear (Opuntia ficus india L.) grown wild in Turkey, Journal of Food Engineering 73 (2006) 198-202.

[15] O. Smith, Potatoes: Production, storing, processing, The AVI publishing company, INC. Westport, Connecticut, 1977.

[16] M. Laza, M.G. Scanlon, G. Mazza, The effect of tuber preheating, temperature and storage time on the mechanical properties of potatoes, Food Research International 341 (2001) 659-667.

[17] R. Noble, The relationship between impact and internal bruising in potato tubers, J. agric. Engng. Res. 32 (1985) 111-121.

[18] M.D. Alvarez, D.E. Saunders, J.F. Vincent, Effect of turgor pressure on the cutting energy of stored potatoes, European Food Research Technology 210 (2000) 331-339.

[19] G.H. Brusewitz, R.E. Pitt, Q. Gao, Effects of time and static preloading on the rheology of potato tissue, Journal of Texture studies 20 (1989) 267-284.

[20] M.G. Scanlon, C.H. Pang, C.G. Billaderis, The effect of osmotic adjustment on the mechanical properties of potato parenchyma, Food Research International 29 (1996) 481-488.

[21] J. Wu, K.Q. Guo, Dynamic viscoelastic behaviour and microstructural changes of Korla pear (Pyrus bretschneideri rehd) under varying turgor levels, Biosystems Engineering 106 (2010) 485-492. 